\title{
A Method for Quantitative Estimation of Leukocyte Peroxidase in Peripheral Blood
}

\author{
By \\ Noriko Katsushima \\ From the Department of Pediatrics, Faculty of Medicine, Tohoku \\ University, Sendai; Director: Prof. Ts. Arakawa \\ (Received for publication, October 10, 1962)
}

For a quantitative estimation of peroxidase in serum or plasma, a new colorimetric method ( $\alpha$-Naphthol-Benzidine Method) was reported in our previous paper. ${ }^{1)}$

The present report concerned a method for quantitative estimation of peroxidase of myeloid cells in the peripheral blood.

\section{THE AUTHOR'S METHOD}

Principle:- "A leukocyte-rich suspension" was prepared from heparinized blood by a sedimentation procedure with dextran-saline. ${ }^{2)}$ Total and differential counts of leukocytes were made upon the "leukocyte-rich suspension" thus obtained. The red cells contaminating "the leukocyte suspension" were eliminated by a complete hemolysis of them by addition of an adequate amount of distilled water. The mixture was centrifuged, and the supernatant layer was discarded; a leukocyte deposit was thus obtained.

Prior to the application of $\alpha$-naphthol-benzidine method ${ }^{1)}$ to the leukocyte deposit, a pre-treatment with trypsin was found to be indispensable for full development of peroxidase activity of each of the leukocytes. The reason for this was that leukocytes tended to agglutinate spontaneously and to form clumps of themselves, consequently not a few leukocytes in the clumps could not come into direct contact with the reagents used in the $\alpha$-naphthol-benzidine method.

Details of procedures:- Two cc of heparinized blood were obtained by vein puncture and put into a small test tube and $1 / 3$ volume of a dextran-saline solution $(6 \%$ dextran in physiologic saline) was added. The content was mixed gently but thoroughly by repeated inversion of the test tube, then the tube was held slanting at an angle of about $45-60$ degrees at $37^{\circ} \mathrm{C}$ for from 30 to 60 minutes. The supernatant layer thus produced was taken up carefully with a capillary 
pipette and "the leukocyte-rich suspension" was obtained. Total and differential counts of the leukocytes were carried out upon "the leukocyte-rich suspension." For the differential stain of smears the Tohoku Pediatric Method ${ }^{3}$ tion of Sato-Sekiya's peroxidase stain $^{6}$ ) was used.

To $0.2-0.5 \mathrm{cc}$ of "the leukocyte-rich suspension" 4 volumes of distilled water were added, then the content was mixed thoroughly in order to have the contaminating red cells hemolyzed, then centrifuged at 2,000 rpm for 10 minutes. The upper layer was pipetted off. To the leukocyte deposit $50 \mu \mathrm{g}$ (100 units) of trypsin (Mochida Co. Ltd., Tokyo, Japan), dissolved in 2 cc of M/15 phosphate buffer of $\mathrm{pH} 5.29$ was added, and the content was mixed thoroughly, then kept for one hour at $37^{\circ} \mathrm{C}$. After the incubation, the content was shaken vigorously, then $4.0 \mathrm{cc}$ of $\mathrm{M} / 15$ phosphate buffer of $\mathrm{pH} 5.29$ (Reagent 1$)^{1)}$ and $2.0 \mathrm{cc}$ of the diluted Hayem solution (Reagent 2) ${ }^{1)}$ were added. $1.0 \mathrm{cc}$ of the $\alpha$-naphthol-benzidine solution (Reagent 3$)^{1}$, and then $2.0 \mathrm{cc}$ of the hydrogen peroxide solution (Reagent 4) $)^{1)}$ were added, and the content was well mixed and kept in a water bath of $23^{\circ} \mathrm{C}$ for 30 minutes. After the incubation $5.0 \mathrm{cc}$ of ethyl acetate were added and the content was mixed thoroughly, the ethyl acetate layer was separated from the aqueous layer. The clear pink color of the ethyl acetate layer was measured electrophotometrically at $500 \mathrm{~m} \mu$.

Pure preparation of horseradish peroxidase (Nutritional Biochemicals Corporation, Cleveland, Ohio, U.S.A.) was used for preparation of a standard curve (cf. Table I \& Fig. 1).

Peroxidase content of each single myeloid cell was calculated in the following way.

Table I. Relation Between Amount of Horseradish Peroxidase and Extinction in the $\alpha$-Naphthol-Benzidine Method

\begin{tabular}{c|c}
\hline $\begin{array}{c}\text { Amount of horseradish } \\
\text { peroxidase }(\gamma)\end{array}$ & $\begin{array}{c}\text { Extinction } \times 10^{3} \\
\text { at } 500 \mathrm{~m} \mu\end{array}$ \\
\hline 0.02 & 54 \\
0.04 & 96 \\
0.06 & 150 \\
0.08 & 170 \\
0.1 & 203 \\
0.15 & 280 \\
0.2 & 345 \\
0.25 & 405 \\
0.3 & 450 \\
0.35 & 475 \\
0.4 & 500 \\
0.45 & 520 \\
0.5 & 535 \\
0.55 & 548 \\
0.6 & 555
\end{tabular}




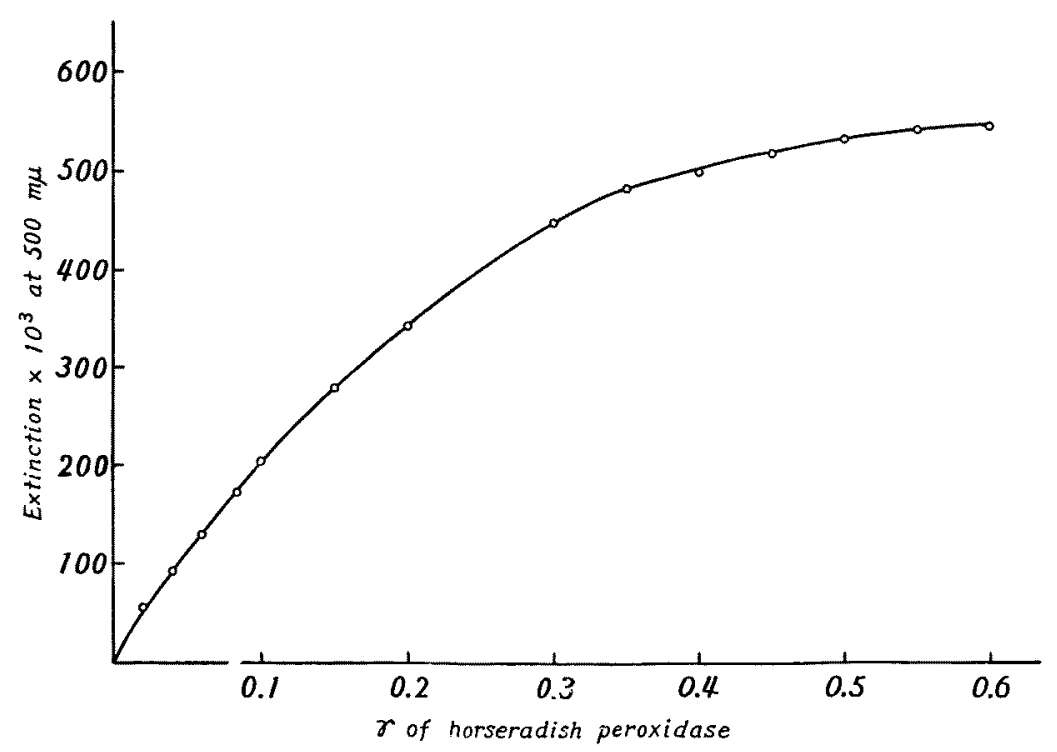

Fig. 1. Relation between amount of horseradish peroxidase and extinction in the a-naphthol-benzidine method. ${ }^{11}$

Peroxidase content of Peroxidase content in "the leukocyte suspension after a single myeloid cell $=\frac{\text { the trypsin-treatment" }}{\text { Total number of myeloid cells in "the leukocyte }}$ suspension after the trypsin-treatment"

In the present paper the term "myeloid cells in the peripheral blood" was used for those cells with positive peroxidase reaction by Tohoku Pediatric Method, ${ }^{3)}$ that is, neutrophils, eosinophils, monocytes, basophils, etc.

\section{RESULTS}

Peroxidase content of myeloid cells from normal adults (cf. Table VI): - An estimation of peroxidase content in myeloid cells was carried out upon 11 normal adults by the author's method and an average was found to be $5.53 \times$ ${ }^{10^{-8}} \gamma$ horseradish peroxidase, per each of myeloid cells.

\section{REMARKS ON EXPERIMENTAL TECHNIQUES}

Preparation of the leukocyte-rich suspension :- A leukocyte-rich suspension was prepared from heparinized blood by a procedure of selective sedimentation of red cells with addition of an adequate amount of the dextran-saline solution. ${ }^{2}$ ) It was found that the optimal ratio was one volume of the dextran-saline to 3 volumes of heparinized blood, because if this ratio was adopted always, then a suspension rich in leukocytes and less contaminated with red cells could be 
obtained irrespective of hematological conditions of subjects to be examined.

Elimination of red cells from the leukocyte-rich suspension by hemolytic procedure: - A considerable number of red cells was found in the leukocyte-rich suspension. The $\alpha$-naphthol-benzidine method would be interfered if the amount of hemoglobin attained a concentration of $6 \mathrm{mg} \%$ or more. ${ }^{1)}$ By the hemolytic procedure as stated above, the red cells contained in the 'leukocyte-rich suspension' was completely destroyed. After the hemolytic procedure, there were no changes in the morphological findings and in the appearance of peroxidase granules stained with the Tohoku Pediatric Method ${ }^{1)}$ while there was no decrease in number of myeloid cells.

Treatment with trypsin of "the leukocyte layer":- As was mentioned above, "the leukocyte layer' was obtained by eliminating red cells from the leukocyte-rich suspension. In the leukocyte layer, the leukocytes tended to agglutinate spontaneously and to form clumps ${ }^{2,4}$ ) of themselves. These clumped leukocytes could not be separated from each other even by vigorous shaking. It was reasonable to assume that clumping of leukocytes interfered with the otherwise complete reaction between the color reagents and peroxidase of each of leukocytes because not a few leukocytes were included within the clumps. It was found that an incubation of a leukcoyte deposit with trypsin in an amount of $25-1,000 \mu \mathrm{g}$ dissolved in $2.0 \mathrm{cc}$ of $\mathrm{M} / 15$ phosphate buffer of $\mathrm{pH} 5.29$ brought about a complete inhibition of clumping of leukocytes. As was shown in Tables II and III, the intensity of the color developed by $\alpha$-naphthol-benzidine method was found stronger in the cases with the trypsin-treatment than in those without it. The optimal time

TABLE II. Influence of Trypsin-Pretreatment upon the Colorimetric Estimation of Peroxidase of Myeloid Cells ( $a$-Naphthol-Benzidine Method)

\begin{tabular}{c|c|c}
\hline & \multicolumn{2}{|c}{ Extinction $\times 10^{3}$ at $500 \mathrm{~m} \mu$} \\
\hline $\begin{array}{c}\text { Amount of } \\
\text { trypsin }(\mu \mathrm{g})\end{array}$ & Experiment 1 & Experiment 2 \\
\hline 0 & 100 & 162 \\
25 & 143 & 173 \\
50 & 148 & 198 \\
150 & 145 & 178 \\
250 & 147 & 190 \\
400 & 135 & 19 \\
500 & 143 & 192 \\
750 & 132 & 196 \\
1,000 & 152 &
\end{tabular}

Note: Incubation mixture consisted of deposit of leukocytes prepared from $0.5 \mathrm{cc}$ of the "leukocyte suspension", and various amounts of trypsin, dissolved in $2 \mathrm{cc}$ of M/15 phosphate buffer of $\mathrm{pH} 5.29$. Incubation was carried out at $37^{\circ}$ for one hour. Counts of myeloid cells in the leukocyte suspensions were $1,800 / \mathrm{mm}^{3}$ and $3,300 / \mathrm{mm}^{3}$ in Experiments 1 and 2, respectively. 
TABLE III. Intensity of Color developed by the $\alpha$-Naphthol-Benzidine Method with or without the Trypsin-Pretreatment upon "Leukocyte Suspensions"

\begin{tabular}{c|c|c|c}
\hline \multirow{2}{*}{ No. of case } & $\begin{array}{c}\text { Count of myeloid } \\
\text { cells per mm }{ }^{3} \text { of the } \\
\text { suspension }\end{array}$ & \multicolumn{2}{|c}{$\begin{array}{r}\text { Extinction } \times 10^{3} \text { at } 500 \mathrm{~m} \mu \text { per } 0.5 \mathrm{ce} \text { of } \\
\text { the suspension }\end{array}$} \\
\cline { 3 - 4 } & $\begin{array}{c}\text { With the } \\
\text { trypsin-treatment* }\end{array}$ & $\begin{array}{c}\text { Without the } \\
\text { trypsin-treatment }\end{array}$ \\
\hline 1 & 2,400 & 255 & 250 \\
2 & 2,950 & 255 & 95 \\
3 & 3,450 & 345 & 330 \\
4 & 4,350 & 296 & 230 \\
6 & 2,350 & 295 & 245 \\
7 & 1,100 & 192 & 172 \\
8 & 1,330 & 132 & 80 \\
& 5,350 & 300 & 100
\end{tabular}

* Note: Trypsin was used in an amount of $50 \mu \mathrm{g}$.

TABLE IV. Incubation Time with Trypsin and its Relation to the Intensity of Color developed by the a-Naphthol-Benzidine Method

\begin{tabular}{c|c}
\hline Incubation time & Extinction $\times 10^{3}$ at $500 \mathrm{~m} \mu$ \\
\hline 0 minutes & 60 \\
10 & 190 \\
20 & 262 \\
30 & 272 \\
40 & 300 \\
60 & 300 \\
90 & 295 \\
120 & 270 \\
3 hours & 250 \\
4 & 255 \\
20 & 295
\end{tabular}

Note: Trypsin was used in an amount of $50 \mu \mathrm{g}$.

for the incubation with trypsin was found to be 40-60 minutes (cf. Table IV).

It was thus established that trypsin-treatment was effective for inhibition of the clumping of leukocytes and that a stronger color reaction developed after an introduction of the trypsin-treatment prior to the addition of color reagents in $\alpha$-naphthol-benzidine method. Until the effectiveness of the trypsintreatment was confirmed, the following various procedures were undertaken in order to release peroxidase from leukocytes; digestion of leukocytes with a large amount of trypsin at neutral $\mathrm{pH}$, repeated freezing and thawing, homogenizing or ultrasonication. It was found that any of these pre-treatment did not give any stronger color reaction of $\alpha$-naphthol-benzidine method than the trypsinpretreatment as was adopted in my own method.

Correlation between the intensity of color reaction of $\alpha$-naphthol-benzidine method and the amounts of myeloid cells subjected to the reaction:-As was shown 
TABLE V. Relation between Amount of Peroxidase found by a-Naphthol-Benzidine Method and the Amount of Myeloid Cells Subjected to the Color Reaction

\begin{tabular}{c|c|c|c}
\hline $\begin{array}{c}\text { Amount of the } \\
\text { suspension of } \\
\text { myeloid cells (cc) }\end{array}$ & \multicolumn{3}{|c}{$\begin{array}{c}\text { Absolute amount of peroxidase } \\
(\gamma \text { as horseradish peroxidase) }\end{array}$} \\
\cline { 2 - 4 } & Case 1 & Case 2 & Case 3 \\
\hline 0.2 & 0.0243 & 0.0771 & 0.0460 \\
0.3 & 0.0380 & 0.1335 & 0.0725 \\
0.4 & 0.0500 & 0.1808 & 0.0971 \\
0.5 & 0.0628 & 0.2333 & 0.1171
\end{tabular}

Note: Counts of myeloid cells in the suspension were $3,120,4,530$ and 3,140 per $\mathrm{mm}^{3}$ in Cases 1,2 , and 3 , respectively.

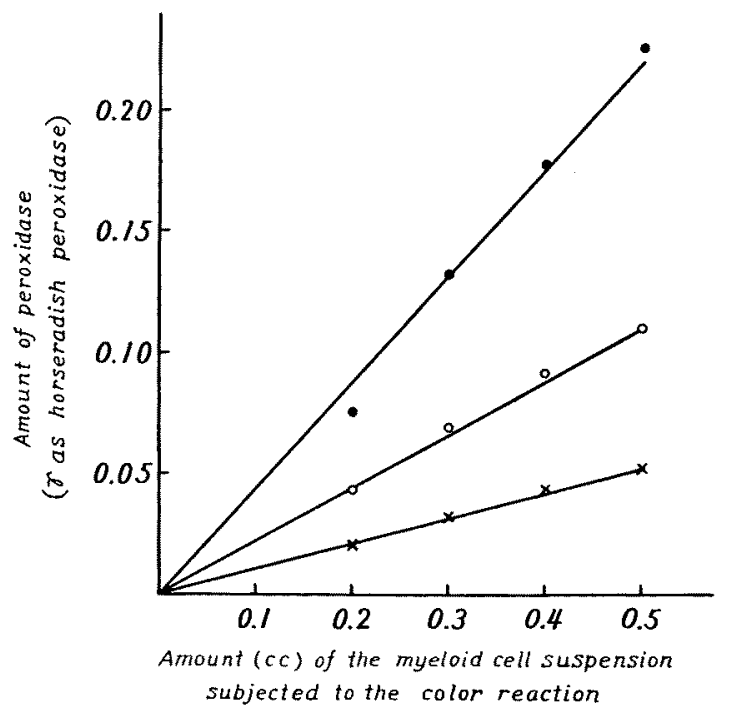

Fig. 2. Relation between the amount of the myeloid cell suspension and the amount of peroxidase found by the color reaction.

$x-\times$ Casel, $\circ-\circ$ Case $2, \cdot-\bullet$ Case 3 .

in Table I and Fig. 1, a good correlation was observed between the intensity of the color reaction and the amount of horseradish peroxidase. At the present time, a pure preparation of verdoperoxidase was not available for us. As will be seen from Table V and Fig. 2, a good response of color development by this method was confirmed in the case of verdoperoxidase (myeloid cell suspension) as in the case of horseradish peroxidase.

\section{DISCUSSION}

In 1941 Agner $\left.{ }^{5,8}\right)$ first isolated and purified the verdoperoxidase from leukocytes, using pus of empyema or leukemic blood. Schultz et al. $\cdot^{9,10,11)}$ have made since 
TABLE VI. Peroxidase Content in Myeloid Cells from Normal Adults

\begin{tabular}{|c|c|c|c|}
\hline No. of case & $\begin{array}{c}\text { Age } \\
\text { (Years) }\end{array}$ & Sex & $\begin{array}{l}\text { Peroxidase content per each of } \\
\text { myeloid cells, expressed as } \gamma \text { of } \\
\text { horseradish peroxidase }\end{array}$ \\
\hline 1 & 26 & 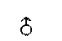 & $4.35 \times 10^{-8}$ \\
\hline 2 & 42 & $\hat{0}$ & 8.07 \\
\hline 3 & 37 & $\delta$ & 4.20 \\
\hline 4 & 34 & $\hat{B}$ & 5.06 \\
\hline 5 & 26 & 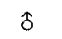 & 5.62 \\
\hline 6 & 26 & 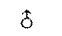 & 5.00 \\
\hline 7 & 20 & 古 & 4.01 \\
\hline 8 & 20 & 5 & 5.50 \\
\hline 9 & 23 & \& & 5.62 \\
\hline 10 & 28 & 웅 & 5.24 \\
\hline \multirow[t]{2}{*}{11} & \multirow[t]{2}{*}{27} & \multirow[t]{2}{*}{ \& } & 6.06 \\
\hline & & & $5.53 \pm 1.23$ \\
\hline
\end{tabular}

1954 an extensive investigation upon peroxidase, especially that of experimental chloroma of rats. Loeb and Doniger determined, using a modified method of Colowick and Kaplan, ${ }^{14}$ ) the myeloperoxidase activity in the bone-marrow from tumor-bearing mice ${ }^{12}$ ) and that in the subcutaneous chloromas of the rats. Kélenji et al. ${ }^{15}$ ) determined, using a modified method of Straus, ${ }^{16}$ ) the myeloperoxidase activity of chloroma, bone-marrow, spleen, liver and lymph nodes from chloroleukemic rats. Neufeld et al. ${ }^{17)}$ estimated the peroxidase and cytochrome oxidase in Walker carcinoma 256 with a method using a leuko dye. ${ }^{18)}$ They also determined the distribution of peroxidase and cytochrome $\mathrm{C}$ oxidase in the various tissues of rats. ${ }^{19)}$

As above quoted, such a recent progress in the studies on peroxidase was made mainly by way of animal experimentation.

A quantitative observation of leukocyte peroxidase in rabbits was undertaken by Sato and Kuribayashi ${ }^{7}$ ) from our Laboratory in 1935, who made a careful counting of the leukocyte granules positive to the peroxidase reaction with Tohoku Pediatric Method, ${ }^{3)}$ a modification of Sato and Sekiya's original method. ${ }^{6)}$ Such a histochemical method could not be applied directly to blood film from human being, because peroxidase granules in a human leukocyte appeared too numerous in number to count precisely under the microscope. Respecting human leukocyte peroxidase, Schultz and Kaminker ${ }^{20)}$ reported in 1962 that peroxidase content was $7.10 \times 10^{-6} \mu \mathrm{g} /$ cell and that peroxidase amounted $6.8 \%$ of the dry weight of leukocytes. They used "Buffy Coat" as a source material of white cells and adopted trypsin for solubilization of peroxidase.

In my own method, trypsin was indeed used, but the purpose was quite different; it was used, as explained above, to bring about an inhibition of clumping of leukocytes. 
Martin et al. ${ }^{21)}$ reported that verdoperoxidase differed from horseradish peroxidase in the ability of oxidation of pyrogallol, leuko dye or reduced cytochrome $\mathrm{C}$ and that verdoperoxidase showed different activity according to the kinds of substances to be oxidized. In connection with this, it may be mentioned that the values of leukocyte peroxidase reported by Schultz and Kaminker (7.10 $\times 10^{-6}$ verdoperoxidase/cell) could not be compared directly with those found by author's own method $\left(5.53 \times 10^{-8} \gamma\right.$ horseradish peroxidase/cell).

Further study on the peroxidase content in leukocytes of the peripheral blood, by using the author's method, is under way and the results in various clinical conditions will be reported soon.

\section{SUMMARY AND CONCLUSIONS}

A new, simple method for quantitative estimation of peroxidase in a single myeloid cell in the peripheral blood was described.

Only $2 \mathrm{cc}$ of blood were required for this assay, so that the present method may be used for clinical research.

\section{References}

1) Katsushima, N. \& Arakawa, Ts., Tohoku J. Exper. Med., 1961, 75, 238.

2) Skoog, W.A. \& Beck, W.S., Blood, 1956, 11, 436.

3) Sato, A. et al., Tohoku J. Exper. Med., 1934, 24, 195.

4) Jullis, J.L., Blood Cells and Plasma Proteins, New York, Academic Press, 1953, quoted from 2).

5) Agner, K., Advances in Enzymology, 1943, 3, 137, Interscience.

6) Sato, A. \& Sekiya, S., Tohoku J. Exper. Med., 1926, 7, 111.

7) Sato, A. \& Kuribayashi, S., ibid., 1935, 35, 522.

8) Agner, K., Acta Physiol. Scand., 1941, 2, Suppl. 3, cited from 5).

9) Schultz, J. et al., Cancer Research, 1954, 14, 157.

10) Schultz, J. et al., ibid., 1956, 16, 569.

11) Schultz, J. \& Shay, H., J. Am. Chem. Soc., 1957, 79, 1632.

12) Loeb, H. G. \& Doniger, R., Brit. J. Cancer, 1958, 12, 669.

13) Loeb, H.G. \& Doniger, R., ibid., 1959, 13, 506.

14) Colowick, S.P. \& Kaplan, N. O., Method in Enzymology, Academic Press, New York, $1955,2,770$.

15) Kélenji, G. et al., Blood, 1961, 18, 417.

16) Straus, W., J. Biophys. Biochem. Cytol., 1958, 4, 541.

17) Neufeld, H.A. et al., Cancer Research, 1955, 15, 550.

18) Lucas, F.V. et al., J. Biol. Chem., 1955, 214, 775.

19) Neufeld, H.A. et al., ibid., 1958, 233, 209.

20) Schultz, J. \& Kaminker, K., Arch. Biochem. Biophys., 1962, 96, 465.

21) Martin, A.P. et al., J. Biol. Chem., 1958, 233, 206. 